\title{
Gendered Punishment Practices Performed on Female Adolescents in their Passage through the Uruguayan Juvenile Justice System
}

OÑATI SOCIO-LEGAL SERIES VOLUME 10, ISSUE 2 (2020), 313-331: EL GÉNERO DE LOS SISTEMAS

PENALES JUVENILES: DEBATES NECESARIOS

DOI LINK: HTTPS://DOI.ORG/10.35295/OSLS.IISL/0000-0000-0000-1070

RECEIVED 20 MARCH 2019, ACCEPTED 17 JULY 2019

\section{LAURA LÓPEZ-GALLEGO* (D)}

\section{Abstract}

This article is based on two research studies conducted on the Uruguayan Juvenile Justice System (UJJS); the first study (2011) examined female adolescent incarceration contexts, and the second one (2016) focused on female adolescents in their passage through a program of non-custodial measures. This research is aimed at understanding gendered punishment practices performed on women who are subjected to judicial measures in the UJJS, in order to give visibility to an issue that is usually silenced, among other reasons because the number of women subjected to these measures is low and due to a hegemonic male model in adolescent offense construction. Following a qualitative methodology research, combined with an ethnographic approach, I discuss the singularities characterizing the passage of female adolescents through the UJJS, by applying two strategies: (re)constructing a lost domesticity and managing bodies and sexualities.

\section{Key words}

Female adolescents; incarceration; Uruguayan juvenile justice system; gender; non-custodial measures

\section{Resumen}

El presente artículo surge de dos investigaciones realizadas en el sistema penal juvenil uruguayo (SPJU); la primera (2011) aborda los contextos de privación de libertad de las adolescentes mujeres, la segunda (2016) trabaja con las adolescentes mujeres en su pasaje por un programa de medidas no privativas de libertad. Los objetivos de estas investigaciones buscan conocer las prácticas de castigo generizadas destinadas a las mujeres que cumplen medidas judiciales en el SPJU, de modo de visibilizar una temática que tiende a ser acallada, entre otras cosas por el escaso número de mujeres que transitan

\footnotetext{
* PhD in Psychology (2016, Universidad Autónoma de Barcelona). Associate full-time professor, School of Psychology, Universidad de la República, Uruguay. Contact details: Tristán Narvaja 1674, C.P. 11100, Montevideo, Uruguay. Email address: $\underline{\text { llopez@psico.edu.uy }}$
} 
por estas medidas y por el modelo hegemónico masculino en las construcciones de la infracción adolescente. A través de una metodología cualitativa de investigación, con enfoque etnográfico discuto las singularidades de los tránsitos de las adolescentes por el SPJU, a través de dos estrategias; la (re)construcción de la domesticidad perdida y la gestión de los cuerpos y las sexualidades.

\section{Palabras clave}

Adolescentes mujeres; privación de libertad; sistema penal juvenil uruguayo; género; medidas no privativas de libertad 


\section{Table of contents}

1. Introduction: Gendered punishment practices performed on women in the UJJS in

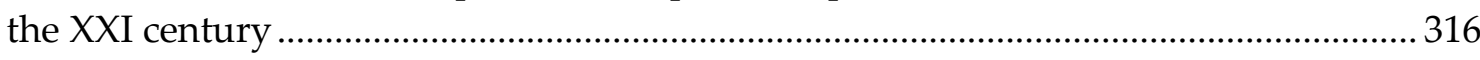

2. Considerations about the Uruguayan juvenile justice system...................................... 317

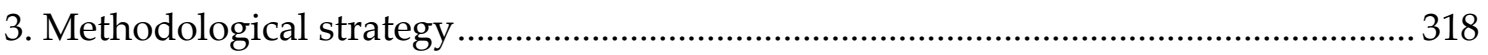

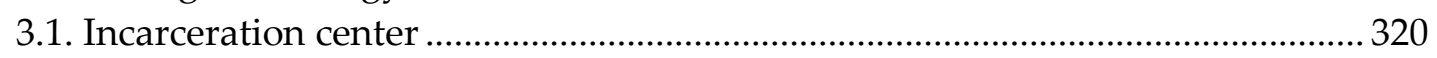

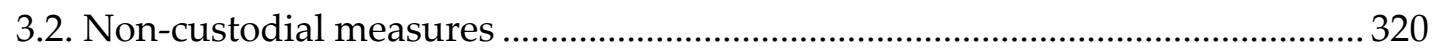

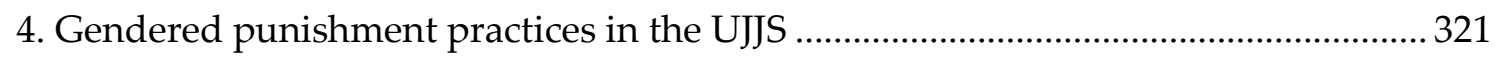

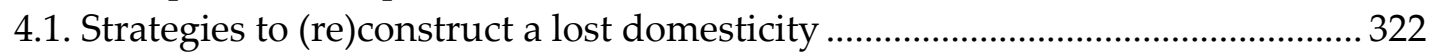

4.2. Strategies for body and sexuality management ................................................... 323

5. Final considerations. Meanings of punishment: Body, guilt and suffering ................ 325

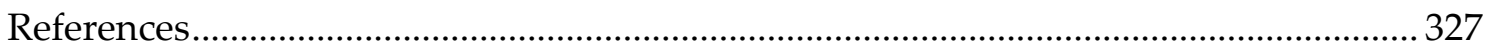

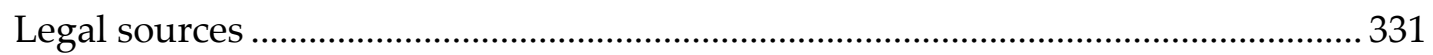




\section{Introduction: Gendered punishment practices performed on women in the UJJS in the XXI century}

In this article I discuss gendered punishment practices performed on female adolescents subjected to judicial measures in the Uruguayan Juvenile Justice System (UJJS), within the framework of the State institution tasked with regulating their enforcement. Reflecting on judicial measures from a female perspective implies exploring an unresearched issue, dominated by a hegemonic male model in adolescent offence construction (Chesney-Lind and Pasko 2013, Galeotti 2013).

Gender is an analytical category (Scott 1996) that intersects with other categories, such as race and social class, composing a heterogeneous field embodied in the kind of treatment designed on female adolescents depending on their deviance from the penal framework in force at a certain socio-historical time. "The contribution of class-racegender to criminology is an insistence that everyone is located in a matrix of multiple social relations, i.e. that race and gender are just relevant to an analysis of white men as they are to black women" (Daly 2013, p. 9).

Feminist movements politicize the notion of gender as a way of combatting a biological determinism that associates sexual difference to female submission. Judith Butler (2001) contributes to this argument by problematizing the sex-gender dichotomy, a binarism that brings the nature-culture divide back to the forefront. She proposes that sex-gender distinction is a product of power relations that produce a "prediscursive sex". Within this framework, it is relevant to include multireferential criteria, such as race and social class, among others, and a socio-historic dimension framing the social practices, among them punishment practices, in their genealogical dimension (López-Gallego 2016).

If gender is a kind of a doing, an incessant activity performed, in part, without one's knowing and without one's willing, it is not for that reason automatic or mechanical. On the contrary, it is a practice of improvisation within a scene of constraint. Moreover, one does not 'do' one's gender alone. One is always 'doing' with or for another, even if the other is only imaginary. (Butler 2006, p. 13)

In this sense, I prioritize a notion of gender devised and built at the intersection of various social technologies, selecting judicial measures as one of the main study focus. Thus, I analyze "gender in criminalization processes" and the singularities related to the passage of women through juvenile justice systems. Questions scrutinize approaches adopted by juvenile justice systems, as producers of gendered punishment practices that operate creating and (re)creating gendered bodies (De Lauretis 1989, Butler 2006, Almeda 2017).

In parallel, feminist criminologists (Birgin 2000a, 2000b, Smart 2000, Pitch 2003, Carlen and Worrall 2004) integrate gender relations as a means of control and domination in the criminal area, justice systems being a privileged area in the construction of socio-penal control practices associated to gendered punishment practices. Justice systems conform "sexuation" modalities and generate gender technologies; how they do all this is one of the focus areas of this study: how do justice systems operate when building sex-gender systems (Rubin 1975).

In turn, juvenile justice systems are selective. In terms of social class and gender, selected women are guilty of a double deviation: crime and gender. Therefore, they are subjected 
to a three-pronged discipline: feminization, domestication and medicalization (Carlen and Worrall 2004). Michel Foucault (1978/1991) has deepened the study of judicial practices, in the understanding that they are a privileged setting for the emergence of new forms of subjectivity. In his research, crime is considered an effect of penality: the law creates illegality, so the political nature of its definition is undeniable. Penality would be a way of managing illegalisms by organizing a field of legalities and illegalities that need to be managed.

A significant feature of these frameworks is the capacity for "differential management of illegalisms", explaining why within a given social and historical organization not everything that is considered illegal receives the same kind of punishment. Certain practices, carried out on the margins of legality, are granted some degree of permission taking into account issues related to race, social class and gender, among others. A hierarchy of disorders is also due to a "differentiation of moral judgements" (Fassin 2018).

\section{Considerations about the Uruguayan juvenile justice system}

In an ampler societal context, Didier Fassin (2018) focuses on the punitive moment affecting different geographical spaces in the last decades, leading him to propose that we are witnessing an "era of punishment". "Crime is the problem; punishment, the solution. In the punitive moment, punishment became the problem" (Fassin 2018, p. 13). More people incarcerated for longer periods of time, compounded with the scope of noncustodial measures imposed on individuals that used to be exempt from socio-penal control. These two aspects are present in the UJJS: by extending and harshening the punishment system, after passing legislation that increased the severity of punishment imposed on adolescents. In July 2011, Law $\mathrm{n}^{\mathrm{0}}$ 18,777 was passed, modifying some sections of the Code on Children and Adolescents (Código de la Niñez y Adolescencia CNA -, Law no 17,823). Most importantly, among other modifications, it created a register for some offenses committed by adolescents; "attempted theft" became a criminal offense; and the duration of precautionary measures was increased from 60 to 90 days. Along this line, Law no 19,055 (January 2013) provided for 15 to 17 years of prison to extremely serious offenses committed by adolescents, with a minimum incarceration time of 12 months.

"Juvenile neopunitivism" has been a characteristic of reforms introduced in recent years on children and adolescents legislation in force: the Code on Children and Adolescents (CNA, Law no 17,823). Several authors (Gallardo 2018, Vinoles 2018, Vizcaíno 2018) have discussed the reactions against reform that have affected Uruguay, alerting on the consequences for some adolescents: from subjects of law to objects of punishment. Various actions compound the punitive moment: harshening of penalties, construction of incarceration centers, bills proposing lowering the age of criminal responsibility, creation of new offenses; a society that is intolerant and selective against some of its individuals, combined with penal populism at the political class, leading to a referendum on lowering the age of criminal responsibility in 2014, in Uruguay.

In turn, these action frameworks are intertwined with high selectivity with justice systems, in terms of socio-economic contexts, leading to the debate of the concepts of "offense" and "crime" that sustain these punitive systems, coinciding with an inclusion 
that is necessary at a larger social scale and is aimed at deploying political rationalities derived from criminalization processes.

This work includes the notion that these people are adolescents - "female minors". Thus, the category "adolescence" will be described as dynamic, subject to a constant social negotiation, i.e. designed as a historical, cultural and political construct that is not an ontological or natural category. The very concepts that define it are, therefore, conditioned by the contexts in which they arise, and are in constant tension by the coming times and by the new requirements they bring about" (Leopold 2014). From an operational perspective, references to the category adolescence will relate to the provisions of the Code on Children and Adolescents (CNA, Law no 17,823), article 1, according to which "an adolescent is a person older than thirteen years and younger than eighteen".

The UJJS is structured in different segments mirroring the stages of the criminal procedure: police, judicial and enforcement of judicial measures, in the CNA identified as socio-educational. Socio-educational measures can be categorized in three large groups, depending on the "confinement" variable: some take place during incarceration, others in a semi-custodial situation, and some others are non-custodial; the latter includes reprimand, guidance and support, community service, reparation or satisfaction to the victim, probation and surveillance.

It should be mentioned that the option of semi-imprisonment does not exist as such for female adolescents, so the discussion included in this article refers to the scenarios of incarceration and non-custodial measures.

\section{Methodological strategy}

By adopting a qualitative and ethnographic perspective to social research (Fassin 2016, Denzin and Lincoln 2017) I intend to: understand the operation of judicial measures in custodial and non-custodial regimes, performed on female adolescents in the Uruguayan juvenile justice system (UJJS), in terms of the goals that are set, the means available to achieve them, the agents and technologies at their disposal, and their effects.

Research is directed at understanding particular situations - operation of judicial measures - in a specific institutional context and/or scenario where judicial measures are implemented - UJJS - through the meanings assigned to them by the agents adolescents, practitioners, officials, researchers - who live or work there.

I adopted an ethnographic perspective (Hammersley and Atkinson 1994, Fassin 2016) as soon as I started spending time in the institution, watching and sharing conversations with different people. I got closer to this methodological perspective as I participated in the life of the institution, generating material related to observations, conversations and informal exchanges, which I recorded in a field diary. In the first study, I devoted approximately one year and a half (2010-2011) to fieldwork, as doctoral thesis research in the Universitat Autònoma de Barcelona, while the second study took an entire year (2016) and was done collectively, financed by Universidad de la República.

Both research processes share characteristics with the ethnographic approach (Guber 2009), as they seek to understand social phenomena from the very perspective of the agents involved by interacting with them. In these frameworks of understanding, 
fieldwork becomes central and entails a co-located, continued and committed presence by researchers in the institutional scenarios where female adolescents serve the judicial measures.

Ethnography is a way of commitment, said Daniel Cefai. First, commitment inside the research, in the relation with the field and its characters, with all the contradicting loyalties and ethical issues it entails. Then, commitment inside the polis, linked to the public space and its debates, with the moral tensions and political challenges it poses. If this study was born partly by chance, reporting on it became necessary for me. (Fassin 2016, p. 62)

The reflection on the analysis, the drafting and the transmission, and the ethical-political dimension are pivotal axes when dealing with underage people placed in contexts where their rights are being abused. As a characteristic of the qualitative dimension, I build an interpretive approach to social processes, wherein analysis in guided by thick description (Geertz 2005) of the meanings assigned by different people to the processes being studied, in this case judicial measures imposed on female adolescents. The notion of thick description underlines inscription as a practice allowing to establish the meaning that certain social actions have for their actors and to enunciate, as explicitly as possible, what the knowledge thus achieved reveals about its relevant society (Geertz 2005, p. 37). More concretely, analysis is about building a meaning for qualitative data, in order to understand the social scenarios on which I conduct my research (Coffey and Atkinson 2005). CAQDAS (Computer Assisted Qualitative Data Analysis Software) was used to support data processing segmentation and coding (Lewins and Silver 2007, Hwang 2008, Konopásek 2008).

The ethical dimension, following Montero (2004), is relational; how we define and include the Other in the production of knowledge. A responsibility for how we (re)present these Others with whom we build knowledge. In this kind of research, there is an additional difficulty regarding the capacity of thinking in terms of co-analysis. On the other hand, the political dimension, as discussed by Fassin $(2016,2018)$ regarding commitment inside the polis, is related to the goal of the research in terms of its application and the social effects of any kind of knowledge.

Some of questions/debate have to do with ethical issues; how we access to enclosed institutions, how we use and consider the free and informed consent of the participants, how we characterize the encounters with the participants, how we write about them, knowing that in many contexts co-writing is difficult to implement in practice, and how confidentiality works and what it means (Freshwater et al. 2012, Abbott et al. 2018). The issue of confidentiality and anonymity becomes important when working in juvenile justice systems. Officials and practitioners are mentioned by their respective occupational function: technical team, management. For the adolescents, we reached a different solution; they want to have a different name, an alias that allows to establish confidentiality and to incarnate in a concrete person, with a tangible materiality (Billig 1994). The tension resides in identifying how much we have to protect and redraw without turning people into somebody else, while preserving a pact of confidentiality that protects participants from harm related to the public dissemination of their testimony. 


\subsection{Incarceration center}

Some 20 adolescents live at the incarceration center, with an average staff of 40 people. Taking into account the permissions obtained in terms of time for the investigation, not more than 6 months, and the time spent by the adolescents at the institution (an average of 3-6 months in the year 2010-2011), it was difficult to interact with all of them. The fact that educators also rotate in several shifts, and that my permit was only valid for the afternoon was also a significant limitation: knowing how the institution works in only one time slot. At first, I did not believe this would be a problematic, given how difficult it was to procure institutional access.

Fieldwork began before I was granted permission to enter the center, by interviewing practitioners, educators and officials that have worked there. This allowed for a gradual knowledge of its operation, a familiarity of sorts that was very useful when mapping out the issues, at an initial stage.

The sample, understood as well-founded decisions adopted when selecting people and scenarios, is intentional or based on criteria, not probabilistic, characteristic of qualitative approaches (Ruiz Olabuénaga 2009). In the first part of the fieldwork, before access to the center, the criteria for selecting informants - educators and practitioners - required participants having worked at the institution for the last 15 years; but, fundamentally, I adopted a selective/strategic sampling, prioritizing access to different people by a snowball mechanism, i.e. one person led me to another.

In the second half of the fieldwork, after I started visiting the center, I established different strategies for adolescents and officials, and practitioners and educators. For the latter, as the center is very small, I tried to make contact with as many people as possible: we managed to hold interviews with all the practitioners and management (four people). In the case of educators, all women by the time the fieldwork was done, I held two interviews, but most the material was taken from informal conversations and field diary notes.

In the case of adolescents, some of the criteria were set before and some after working with them: according to the Code on Children and Adolescents (CNA), ages are divided into two period, 13-15 years and 16-17 years; geographical origin (Capital City vs. Rest of the Country); first-timer vs. recidivist in the UJJS; and, lastly, the condition of having children or not. In the context of fieldwork, I added the criteria of pregnancy, taking into account the different effects this produces; for example, a pregnancy meant that no psychotropics were administered. I established contact with nine adolescents, and I held 2-3 meetings with them.

\subsection{Non-custodial measures}

The methodological strategy comprised two moments; during the first, we worked on institutional access, through interviews with officials to negotiate permissions and the characteristics of the fieldwork to be done. Authorities were welcoming throughout the study, unlike our experience in the previous study, when access to the center was very difficult to obtain. This "open-door" policy improved conditions to researchers, confirming that institutional access informs the scenarios on which we work, making a valuable analytical contribution. 
The second half of the fieldwork entailed accompanying four female adolescents in their institutional passage after judicial measures were imposed. This included participating in interviews conducted by practitioners, observing the institutional spaces and recording all activities in a field diary. The qualitative sample included all the female adolescents having entered the non-custodial measure program in a six-month period, and had a strategic component (Ritchie and Lewis 2003), as not all practitioners accepted the participation of the researchers in the process. Another challenge for fieldwork was the absences and abandonment that characterize this kind of measures. Frequently, they attend a few initial interviews and then quit, sometimes they do not show up at all. Aspects that show us the institutional functioning.

\section{Gendered punishment practices in the UJJS}

In his research on punishment, Fassin $(2016,2018)$ claims that Western societies have moved from a logic of reparation to a logic of punishment, characterized by a moral economy, where suffering plays a central role.

From the initial definition, the only thing that has survived is one single criterion: inflicting punishment, something that according to genealogical research was not always part of the response to a violation of social codes, and that is rooted in the moralization of penalties, of Christian inspiration. (Fassin 2018, p. 99)

Regarding punishment practices performed on females in juvenile justice systems, the weight of religiousness and suffering is relevant. Traditionally, the notion of crime has been associated to men - preferably poor and racially-connoted: black, indigenous while women have been associated to notions related to sin, carrying a heavy religiousmoralist connotation (Juliano 2009).

Local and international historical research (Reyes 1946/1989, Almeda 2002, Aguirre 2008) place the appearance of the cloister model in the treatment of deviant women, characterized by training women for domestic labor akin to indentured servitude. "Galley houses" and "correctional houses" arrive in Latin America in the late XIX century, introduced by the Congregation of Our Lady of Charity of the Good Shepherd. They establish their presence in Uruguay in 1876. Although Uruguay had begun a process of secularization and had mandated laicity for all public institutions at the turn of the XX century, both female adolescents and adult women were kept under a hybrid regime for the entire century, practically.

State institutions connected with a religious activity by configuring singular punishment practices, in which psychological and physical suffering was a pillar of interventions performed by nuns on female adolescents. One of the few written testimonies from the time that has survived is a book on Adolescent Psychology and Reeducation, written by Reina Reyes in 1946, while working as a psychologist and teacher at Feminine Center no 1, part of the Child Council, at the time, the institution tasked with implementing child welfare policy. The custodial approach was based on inflicting physical and psychological punishment in response to sexual behavior displayed by adolescents, as well as a rigid discipline centered on "sin" and threats of afterlife punishments. The author puts forward an unconscious explanation, linking the infliction of punishment to the repression of her own sexual instinct (vow of chastity). "It should be mentioned that inflicting punishment satisfies the aggressive tendencies of those in charge, reinforcing 
the inhibition of forbidden behaviors, but still wanted unconsciously (...)" (Reyes 1946/1989, p. 22).

These sustained punishment practices are a religious hybrid, and reinforce the custody model of the time, which prioritizes a technology that focusses on morally reforming the adolescents through different strategies: assimilation of crime to sin, a strong discipline applied to the body - and in particular to the sexuality of adolescents, and the imposition of female models in which women were mothers, housewives and/or maids.

In this section, I discuss the body-sexuality-domesticity triad as central components of punishment practices inflicted on female adolescents in the UJJS, establishing that there is a significant difference of intensity when the penalty carries incarceration time.

\subsection{Strategies to (re)construct a lost domesticity}

In a historical and current research study conducted in Spanish prisons, Almeda (2002) analyzes the contents of justice system rehabilitation practices imposed on women, targeting what she calls "reconstruction of a lost domesticity".

-What I like is (...) when I raise my kid, I want to work somewhere where I can clean... clean.

-Do you like it?

-I love cleaning.

-You like cleaning. Did you help your mom?

-I used to clean my room, but sometimes I would help around; when mom, when no one was home, I'd clean the entire house. (María, incarceration, interviewed in 2010)

Elisa tells us about her routine. She goes to bed at $5 \mathrm{am}$, because at night, when her mother is back from work, she goes out with her friends, dancing, playing cards, chatting, etc. She wakes up at 1-2 pm, takes a shower, cleans the house and makes food for her family. Sometimes she takes her sister to school and in the afternoon she babysits her nephews, at her sister's home in the neighborhood. Hearing this description, we tell her that, in fact, some of her responsibilities could be defined as work related to the care of others and of her own home. She acts surprised, for her this is something totally natural. (Elisa, non-custodial measure, field diary, 2016)

The particularization processes of childhood and adolescence as biopolitical strategies carry the markings of social class and gender. Fernández (1993) points out that care work, forced maternity and commercial sexual exploitation will be some of the components in the passage into adolescence by girls from poor backgrounds. In addition, the workload related to care work remains unseen, and the time and responsibility it requires cannot be assessed (Carrasco et al. 2011).

Then, on the one hand, Maria speaks to us of a life projection where she aspires to domestic and care work, what is familiar to her, and the way she finds to financially support her future child, while Elisa describes a routine in which caring for nephews and siblings, in addition to her chores, are the activities she carries out daily. Research carried out on this subject in Uruguay maintains that in poor sectors, it is the family, and more specifically sisters older than 10 years, who are in charge of caring for others as well as of the house chores, to the detriment of other activities such as studying, recreation, and so on (Katzkowicz et al. 2015, Bathyánny et al. 2017). 
For their part, the socio-educational proposals of juvenile justice systems reinforce these stereotyped gender roles through the activities they offer and the moral economies that underpin interventions. Within the framework of these moral economies, care work is not viewed by technical operators as a workload linked to limitations to develop in other areas of life. These adolescents are placed in a gender role that turns them into caregivers through traditional ideals of care associated with love for others, especially for the family (López-Gallego and Montes 2016).

Males get to work in some productive activities; for females, workshop training revolves around hairdressing (...), it's like capturing the other, the 'domestic being'. But everything goes towards (...) I also believe that the 'rehabilitation', between quotation marks, of women is accomplished when you find a boyfriend or become a hairdressing student. And confinement devices like that reproduce the exact same thing, it's like a question of gender overpowering. (Technical operator 1, custodial regime, interviewed in 2011)

Gender overpowering and/or gender penality, the UJJS sets hegemonic meanings about femininity, in many cases coinciding with and reinforcing models already assimilated by these adolescents, in a societal context in which patriarchy associated to capitalism configures subjectivities hatched by domination and exclusion processes (Federici 2013).

\subsection{Strategies for body and sexuality management}

The strategies of domesticity are woven into the bodies of these women, sexuality management being a privileged space of socio-penal control. Bodies that are perceived as rebellious, sexualities that are lived as dangerous, hide and invisibilize the marks of bodies that have been violated and abused. According to research on the subject, the majority of female adolescents who come to the justice system have a history of abuse and diverse forms of commercial and non-commercial sexual exploitation, and sometimes are re-victimized while in confinement (Chesney-Lind and Pasko 2013, López-Gallego et al. 2018).

Galeotti (2016) refers to the notion of "sexual violence denial" within the framework of socio-educational measures for female adolescents to describe the process by which technical operators become aware of abuse and violence suffered by young women and fail to integrate these experiences into the intervention strategies they design. Some research (Chesney-Lind and Pasko 2013, Acale Sánchez 2017) underline that victimization processes lead to criminalization processes. Many young women flee their homes escaping abuse, but then are returned to their families after being processed through the justice system, thus invisibilizing the situation that led them to flee.

Lucrecia says that the most difficult part of the abusive situation she experienced with her grandfather was the silence and the lack of reporting by her family.

-Could you tell your mom?

-Yes, when I left I grabbed the bike and I got there, the first thing I did was pick up the phone and I tell Mom, and Mom started crying. She couldn't believe it and her friend talked to me, Mom was at work and I told her everything and then the whole family came to ask me how it had happened. I told them everything and you know they didn't report it, they didn't do anything. You know why? Because they didn't want to drag the family name in the mud, because my cousin is a doctor, and another is a lawyer, I don't 
know. But why didn't they report it? Well, that's all there is to it. For three years we didn't go to my grandmother's house. (Lucrecia, incarceration, interviewed in 2010)

On the other hand, regarding the care provided to female adolescents, in many occasions emphasis is made by practitioners in sexual and reproductive health care, prioritizing adolescent pregnancy, over other issues. Pitch (2009) uses the term "sexual prevention" to refer to these strategies, which in the UJJS are associated with gendered punishment practices. In these frameworks, sexuality is one of the central aspects to be assessed by technical and legal operators, through two dimensions: on the one hand, it is used to diagnose the adaptation of adolescents to the prevailing social codes and, on the other hand, it is evaluated as uncontrollable and irresponsible, needing to be redirected through medicalization and psychological processes, among others (Carlen and Worrall 2004).

In the second interview, L. (technical operator) specifically asks her about the topic of couple and sexual relations ('I am surprised that she asks the question so directly, it seems part of a protocol'). She answers that she has been dating someone for a month, the brother of a friend, but she says that his parents look after him very carefully. That baffles her, she likes him very much; she clarifies that they haven't had sex yet. L. (technical operator) asks her repeatedly about medical check-ups. Celia responds she is concerned about her oral, not her gynecological health. (Celia, non-custodial measure, field diary, 2016)

Sexualization (Montes-Maldonado et al. 2018) understood as a strategy conferring sexual character to various dimensions of these young women's lives operates as the opposite of the renegation of sexual violence. "For women, what is considered a sin is basically the autonomous use of their sexuality" (Juliano 2009, p. 82). Sin assimilated to a crime shows that religious morality has permeated penal punishment of women. In this scenario, the accusation of prostitution, not understood in terms of sexual exploitation, is cast repeatedly.

In subsequent meetings, we work with Celia to identify any adults who can take care of her. She keeps repeating 'There's me'; it's very difficult for us to accept. They talk to her mother, they talk to her father, they can't take care of her. An arrangement is made so that she can go and visit her sister, who is in custody.

Celia misses the last scheduled interviews, one of the practitioners visits her at her new home, no longer at her friend's. She moved to an apartment with other friends. New suspicions arise about commercial sexual exploitation, referred as 'prostitution', being her means of life; she says that she is working as a nanny. (Celia, non-custodial measure, field diary, 2016)

According to Pitch (2003) freedom, as autonomy for women is located in the body, in the domain of these bodies, which have historically been somebody else's bodies, subject to the public domain from various discourses: medical, legal, political, pedagogical. "In other words, it has been, and still is, the object of law and the rights of others, as a nonautonomous body, subject to heteronomous powers: marital, legal, moral, religious, sanitary" (Ferrajoli 1998/2003, p. 11).

In a context characterized by a custodial-religious hybridization, the infantilization processes suffered by these adolescents place them in a position of need and dependence. The historical plot that unites custody with religion makes underage women, who face the double challenge of being women and minors, even more 
vulnerable. "Girls continue to be considered especially incomplete subjects of rights" (Bodelón and Aedo 2015, p. 233).

For their part, some researchers (Igareda 2009, Lagarde 2014) argue that prison interventions reinforce the equation "woman" equals "mother", as an essential mandate linked to being a woman. From this equalization comes another, "bad mother" equals "criminal". The moral assessment of whether they are good or bad mothers is present, associated to the transgression of gender mandates, and to the socio-sexual morality (Hernández 2013) of the personnel responsible for executing punishment measures.

And girls aren't ready to be mothers because there's no recipe for that. You have to teach them everything, double work! Taking care of the mother, taking care of the baby (...). (Institutional official, custodial regime, interviewed in 2011)

Somehow, I don't know (...) the intention is strengthening their motherhood. Now, if we have a bad mother (...). (Technical operator 3, custodial regime, interviewed in 2010)

In the specific case of women, there are specific international (Bangkok Rules, 2010) and national (Art. 8 of Law n⿳0 17,897, 2005) regulations providing explicitly that for pregnant women in the last trimester, women in the first months of breastfeeding and those who have young children in their care, a non-custodial sentence should be considered, bearing in mind the harmful repercussions of imprisonment on the lives of these children. These aspects are often ignored in juvenile justice systems.

\section{Final considerations. Meanings of punishment: Body, guilt and suffering}

Historically, gender constructions built by law, and especially criminal law, have perpetuated and made possible relations of domination for women, through mechanisms that invisibilize and domesticate them, turning them into "objects of law". The law has reserved spaces for women bound to the private sphere, to biological maternity wards and to the control of their bodies. Justice system build domination relationships through various mechanisms, containing both discrimination and equalization processes. Feminist demands for equal justice at the formal level do not necessarily mean equality, given that the norms are applied to people with profound social inequalities (Fries and Matus 2000, Bodelón 2003).

In the case of underage women, juvenile justice systems are not only selective with issues of poverty and lack of social protection, but their offenses violate feminine nature by coming dangerously close to masculine behaviors: a double selectivity that configures punishments. The questions are about how gendered punishment practices are when one shares the imprecise categorization of being part woman, part girl. If justice systems historically place women in the same category as children, being a girl and a woman entails a double violation that entails processes of infantilization and custody. The bodyguilt-suffering triad is intensified by the religious component that is updated in punishment practices. The hybridization custody-religion will impose an additional control on women, characterized by the infliction of physical and psychological punishment on the bodies of these adolescents. The domesticity of these bodies, lived as rebellious, will focus on the field of sexualities (López-Gallego et al. 2018).

Based on the research carried out in the UJJS, I reflect on how juvenile justice systems produce gendered bodies through their punishment practices, in relation to two 
strategies that intertwine: the (re)construction of a lost domesticity and the management of bodies and sexualities. Within these frameworks, it becomes a priority to place gender relations as a guiding principle of the practices and discourses of juvenile justice systems, in order to analyze the technologies that operate fixing univocal meanings about what being a woman implies. Although the investigations are marked by a local context that characterizes the UJJS, other researchers (Carlen and Worrall 2004, Chesney-Lind and Pasko 2013, Almeda 2017) seem to suggest that some of these questions are transferable to other space-times: the control and the disciplining of the bodies seem to be a historical constant in the approach to women in the justice system.

It is necessary that these aspects be visualized by the key agents dealing with these young women. In this sense, the challenges of intervention with these young women are being able to broaden the field of possibilities, problematizing the hegemonic mandates of "being a woman", while finding formative proposals that can have a meaning and a continuity in the outside, in order to broaden work and personal horizons. On the other hand, the invisible work they carry out in their daily lives must be taken into account when designing exit policies, since it affects autonomy and gravitates on the possibility of being able to sustain training and/or work proposals. It becomes necessary to reassess the issue, that is, to make it visible as a problem, in order to be able to establish the necessary articulations to existing social care policies.

Some research (Carlen 2010) argues that stigmatization processes related to a punitivecustodial history are greater in women than in men. This determines that women who graduate from the juvenile justice system are in risk of great vulnerability in terms of possible situations of sexual abuse, violence, housing problems and reinsertion into work and education. Some of these stigmas become emblems that particularize the young women who transited through these spaces (Reguillo 2000). The necessary connection with the social policy apparatus that can give support and continuity to criminal policies, differing from them, is one of the main challenges faced by juvenile justice systems.

Finally, in terms of research practices, it should be pointed out that access to incarceration centers is very difficult. Fassin (2016) warns about the tensions involved in carrying out ethnographies in the State; he thinks the difficulties in access in terms of "subtraction of the State from the gaze of the researcher, and therefore of the citizen" (Fassin 2016, p. 42). For his part, he puts forward an ethical-political commitment that restores to citizens the knowledge produced by academia in these spaces of state management.

In this sense, by revealing what is generally hidden - or simply ignored - the ethnographer restores to citizens their responsibility to know what is happening and to participate in the public sphere, and restores to individuals and groups affected by these policies the right to have their experience recognized and their voice heard. (Fassin 2016, p. 26)

Research policies in state institutions of confinement have the ethical-methodological possibilities of attempting to account for and denounce the management of what we can define in terms of unlivable life forms (Butler 2017). I have some questions regarding these claims: whose voice is heard, that of the researcher? How can we weave voices and turn the drafting of an ethnography into a polyphonic and dialogical plot? How does the 
right to have the experience recognized relate to the possible abuse that this can generate? Knowing more about some affected groups does not necessarily bring about improvements in their specific living conditions. These questions remain open and stress the forms of use and circulation that I, as a researcher, can make of the narratives produced.

\section{References}

Abbott, P., et al., 2018. A Scoping Review of Qualitative Research Methods Used with People in Prison. International Journal of Qualitative Methods [online], V.17, pp. 115. Available from: https://doi.org/10.1177/1609406918803824 [Accessed 12 April 2019].

Acale Sánchez, M., 2017. El género como factor condicionante de la victimización y de la criminalidad femenina. Papers [online], 102(2), 231-259. Available from: http://doi.org/10.5565/rev/papers.2337 [Accessed 29 July 2019].

Aguirre, C., 2008. Denle duro que no siente: Poder y transgresión en el Perú Republicano. Lima: Pedagógico San Marcos.

Almeda, E., 2002. Corregir y castigar: El ayer y hoy de las cárceles de mujeres. Barcelona: Bellaterra.

Almeda, E., 2017. Criminologías feministas, investigación y cárceles de mujeres en España. Papers [online], 102(2), 151-181. Available from: http://doi.org/10.5565/rev/papers.2343 [Accessed 29 July 2019].

Batthyány, K., Genta, N., and Perrotta, V., 2017. El aporte de las familias y las mujeres a los cuidados no remunerados en salud en Uruguay. Revista Estudos Feministas [online], 25(1), 187-213. Available from: http://doi.org/10.1590/18069584.2017v25n1p187 [Accessed 29 July 2019].

Billig, M., 1994. Repopulating the Depopulated Pages of Social Psychology. Theory and Psychology [online], 4(3), 307-335. Available from: https://doi.org/10.1177/0959354394043001 [Accessed 29 July 2019].

Birgin, H., ed., 2000a. El Derecho en el Género y el Género en el Derecho. Buenos Aires: Biblos.

Birgin, H., ed., 2000b. Las trampas del poder punitivo: El Género del Derecho Penal. Buenos Aires: Biblos.

Bodelón, E., 2003. Género y sistema penal: los derechos de las mujeres en el sistema penal. In: R. Bergalli, ed., Sistemas penales y problemas sociales. Valencia: Tirant lo Blanch, pp. 451-486.

Bodelón, E., and Aedo, M., 2015. Las niñas en el sistema de Justicia Penal. Anales de la Cátedra Francisco Suárez [online], 49, 219-236. Available from: http://revistaseug.ugr.es/index.php/acfs/article/viewFile/3283/3311 [Accessed 29 July 2019].

Butler, J., 2001. El género en disputa: El feminismo y la subversión de la identidad. Trans.: M.A. Muñoz. Ciudad de México: Paidós.

Butler, J., 2006. Deshacer el género. Trans.: P. Soley-Beltrán. Barcelona: Paidós. 
Butler, J., 2017. Cuerpos aliados y lucha política: Hacia una teoría performativa de la asamblea. Trans.: M.J. Viejo Pérez. Buenos Aires: Paidós.

Carlen, P., 2010. A Criminological Imagination: Essays on Justice, Punishment, Discourse. Farnham: Ashgate.

Carlen, P., and Worrall, A., 2004. Analysing Women's Imprisonment. London: Willan.

Carrasco, C., Borderías, C., and Torns, T., 2011. El trabajo de cuidados: Historia, teoría y políticas. Madrid: Catarata.

Chesney-Lind, M., and Pasko, L., 2013. Girls, Women, and Crime: Selected Readings. Thousand Oaks: Sage.

Coffey, A., and Atkinson, P., 2005. Encontrar el sentido a los datos cualitativos: Estrategias complementarias de investigación. Universidad de Alicante.

Daly, K., 2013. Different Ways of Conceptualizing Sex/Gender in Feminist Theory and Their Implications for Criminology. In: M. Chesney-Lind and L. Pasko, eds., Girls, Women and Crime: Selected Readings. Los Angeles: Sage, pp. 3-19.

De Lauretis, T., 1989. Technologies of Gender: Essays on Theory, Film and Fiction. London: Macmillan Palgrave.

Denzin, N., and Lincoln, Y., eds., 2017. The SAGE Handbook of Qualitative Research. London: Sage.

Fassin, D., 2016. La fuerza del orden: Una etnografía del accionar policial en las periferias urbanas. Trans.: A. Sosa Varrotti. Buenos Aires: Siglo XXI.

Fassin, D., 2018. Castigar. Buenos Aires: Adriana Hidalgo.

Federici, S., 2013. Revolución en punto cero: Trabajo doméstico, reproducción y luchas feministas [online]. Madrid: Traficantes de Sueños. Available from: https://www.traficantes.net/sites/default/files/pdfs/Revolucion $\% 20 \mathrm{en} \% 20$ punto $\%$ 20cero-TdS.pdf [Accessed 29 July 2019].

Fernández, A.M., 1993. La invención de la niña. Buenos Aires: UNICEF-XEROX.

Ferrajoli, L., 2003. Prólogo. In: T. Pitch, ed., Un derecho para dos: La construcción jurídica de género, sexo y sexualidad. Madrid: Trotta, pp. 11-17. (Originally published in 1998).

Foucault, M., 1991. La verdad y las formas jurídicas. Barcelona: Gedisa. (Originally published in 1978).

Freshwater, D., et al., 2012. Art and Science in Health Care Research: Pushing at Open Doors or Locked in Institutions? Qualitative Health Research [online], 22(9), 11761183. Available from: https://doi.org/10.1177/1049732312449206 [Accessed 29 July 2019].

Fries, L., and Matus, V., 2000. La ley hace al delito. Santiago de Chile: LOM / La Morada.

Galeotti, R., 2013. Adolescentes infractoras: Discursos y prácticas del Sistema Penal Juvenil Uruguayo. Montevideo: Psicolibros-Waslala. 
Galeotti, R., 2016. La sexualidad paradojal en las intervenciones sociopenales con adolescentes mujeres: La denegación de las violencias sexuales [online]. Available from:

https://www.cbb.org.uy/dbdocs/Docs secciones/nid 90/1.Adolescentes y privacion de libertad Aportes ac ademicos al debate.pdf [Accessed 29 July 2019].

Gallardo, L., 2018. Reformas de contrarreforma. La devaluación de la ciudadanía de algunas adolescencias. In: C. González and S. Leopold, eds., Cuadernos del Diploma en Penalidad Juvenil. Marcha atrás. Reformas legislativas al Código de la Niñez y la Adolescencia en Uruguay. Montevideo: Casa Bertolt Brecht / CSIC, UR, pp. 27-44.

Geertz, C., 2005. La interpretación de las culturas. Trans.: A.L. Bixio. Barcelona: Gedisa.

Guber, R., 2009. El salvaje metropolitano: Reconstrucción del conocimiento social en el trabajo de campo. Buenos Aires: Paidós.

Hammersley, M., and Atkinson, P., 1994. Etnografía: Métodos de investigación. Barcelona: Paidós.

Hernández, F., 2013. Cárceles de mujeres del novecientos: Una práctica de siglos. In: P. Oliver, ed., El siglo de los castigos: Prisión y formas carcelarias en la España del siglo XX. Madrid: Anthropos.

Hwang, S., 2008. Utilizing Qualitative Data Analysis Software. Social Science Computer Review [online], 26(4), 519-527. Available from: https://doi.org/10.1177/0894439307312485 [Accessed 29 July 2019].

Igareda, N., 2009. La maternidad de las mujeres presas. In: G. Nicolás and E. Bodelón, eds., Género y dominación: Críticas feministas del derecho y el poder. Barcelona: Anthropos / OSPDH, pp. 159-194.

Juliano, D., 2009. Delito y pecado: La transgresión en femenino. Política y Sociedad [online], 46(1-2), 79-95. Available from: https://revistas.ucm.es/index.php/POSO/article/view/POSO0909130079A [Accessed 29 July 2019].

Katzkowicz, S., et al., 2015. El trabajo de cuidados desde una perspectiva de género y generaciones. Montevideo: INJU-MIDES.

Konopásek, Z., 2008. Making Thinking Visible with Atlas.ti: Computer Assisted Qualitative Analysis as Textual Practices. Forum Qualitative Social Research [online], 9(2), 2-21. Available from: http://www.qualitativeresearch.net/index.php/fqs/article/viewArticle/420 [Accessed 29 July 2019].

Lagarde, M., 2014. Los cautiverios de las mujeres: Madresposas, monjas, putas, presas y locas. Ciudad de México: Siglo XXI / UNAM.

Leopold, S., 2014. Los laberintos de la infancia: Discursos, representaciones y crítica. Montevideo: Ediciones Universitarias.

Lewins, A., and Silver, C., 2007. Using Software in Qualitative Reseach: A Step-By-step Guide. London: Sage.

López-Gallego, L., 2016. Prácticas de control socio-penal: dispositivo psi pericial y adolescentes mujeres en el sistema penal juvenil uruguayo [online]. Thesis, $\mathrm{PhD}$. 
Universitat Autònoma de Barcelona. Available from:

https://www.tdx.cat/bitstream/handle/10803/368186/1lg1de1.pdf [Accessed 29 July 2019].

López-Gallego, L., and Montes, C., 2016. Domesticidad y cuidados. Acerca de las adolescentes mujeres en su tránsito por los Sistemas Penales Juveniles. In: Casa Bertolt Brecht, ed., Adolescentes y privación de libertad en Uruguay: aportes académicos al debate. Montevideo: Fundación Rosa Luxemburgo.

López-Gallego, L., Galeotti-Galmes, R., and Montes-Maldonado, C., 2018. Gestión de las sexualidades en los sistemas penales: las adolescentes mujeres. Revista Latinoamericana de Ciencias Sociales, Niñez y Juventud [online], 16(1), 413-426. Available from: http://revistaumanizales.cinde.org.co/rlcsnj/index.php/RevistaLatinoamericana/article/view/3180 [Accessed 29 July 2019].

Montero, M., 2004. Introducción a la psicología comunitaria: Desarrollo, conceptos y procesos. Buenos Aires: Paidós.

Montes Maldonado, C., López-Gallego, L., and Galeotti Galmes, R., 2018. Adolescentes mujeres y medidas no privativas de libertad: Narrativas de una experiencia etnográfica. Psicoperspectivas [online], 17(2). Available from: https://doi.org/10.5027/psicoperspectivas-vol17-issue2-fulltext-1212 [Accessed 29 July 2019].

Pitch, T., 2003. Un derecho para dos: La construcción jurídica de género, sexo y sexualidad. Madrid: Trotta.

Pitch, T., 2009. La sociedad de la prevención. Buenos Aires: Ad-Hoc.

Reguillo, R., 2000. Emergencia de las culturas juveniles: Estrategias del desencanto. Buenos Aires: Norma.

Reyes, R., 1989. Psicología y Reeducación de la adolescente. Montevideo: EPPAL-CFEE. (Originally published in 1946).

Ritchie, J., and Lewis, J., eds., 2003. Qualitative Research Practice: A Guide for Social Science Students and Researchers. London: Sage.

Rubin, G., 1975. The Traffic in Women: Notes toward a Political Economy of Sex. In: R. Reiter, ed., Toward an Antropology of Women. New York: Monthly Review, pp. 157210.

Ruiz Olabuénaga, J.I., 2009. Metodología de la investigación cualitativa. Bilbao: Universidad de Deusto.

Scott, J., 1996. El género: una categoría útil para el análisis histórico. In: M. Lamas, ed., El género: la construcción cultural de la diferencia. Ciudad de México: UNAM, Programa Universitario de Estudios de Género, pp. 265-302.

Smart, C., 2000. La teoría feminista y el discurso jurídico. In: H. Birgin, ed., El derecho en el género y el género en el derecho. Buenos Aires: Biblos, pp. 31-71.

Vinoles, C., 2018. Del dicho al hecho: La normativa para adolescentes en conflicto con la ley. In: C. González and S. Leopold, eds., Cuadernos del diploma en penalidad 
juvenil. Marcha atrás. Reformas legislativas al Código de la Niñez y la Adolescencia en Uruguay. Montevideo: Casa Bertolt Brecht / CSIC / UR, pp. 9-26.

Vizcaíno, L., 2018. Efectos normativos y discursivos del neopunitivismo juvenil en Uruguay. In: C. González and S. Leopold, eds., Cuadernos del diploma en penalidad juvenil. Marcha atrás. Reformas legislativas al Código de la Niñez y la Adolescencia en Uruguay. Montevideo: Casa Bertolt Brecht / CSIC / UR, pp. 45-58.

Legal sources

Ley № 17.823. Código de la Niñez y Adolescencia. D.O. [online], nº 26586, of 14 September 2004. Available from:

https://www.oas.org/dil/esp/Codigo Ninez Adolescencia Uruguay.pdf [Accessed 29 July 2019].

Ley № 17.897. Libertad Provisional y Anticipada. D.O. [online], no 26835, of 19 September 2005. Available from:

https://tbinternet.ohchr.org/Treaties/CAT/Shared\%20Documents/URY/INT CAT ADR URY 16754 S.pdf [Accessed 29 July 2019].

Ley № 18.777. Instituto de Responsabilidad Penal Adolescente. D.O. [online], no 228271, of 25 July 2011. Available from: http://badaj.org/wpcontent/uploads/2014/07/Ley\%2018771\%20Instituto\%20de\%20Responsabilidad\% 20Penal\%20Adoelscente.pdf [Accessed 29 July 2019].

Ley № 19.055. Código de la Niñez y la Adolescencia. Se modifican los artículos 72 y 76 y se establece un régimen especial para adolescentes mayores de quince y menores de dieciocho. D.O. [online], $\mathrm{n}^{\mathrm{0}}$ 28642, of 22 January 2013. Available from: https://legislativo.parlamento.gub.uy/temporales/leytemp4760386.htm [Accessed 29 July 2019].

The Bangkok Rules. United Nations Rules for the Treatment of Women Prisoners and Noncustodial Measures for Women Offenders with their Commentary, 2010. Vienna: United Nations Office on Drugs and Crime. Available from: https://www.unodc.org/documents/justice-and-prisonreform/Bangkok_Rules_ENG_22032015.pdf [Accessed 29 July 2019]. 